\title{
КОНСТРУЮВАННЯ «Я-ОБРАЗУ» СТУДЕНТІВ ВИЩИХ НАВЧАЛЬНИХ ЗАКЛАДІВ УКРАЇНИ В ЛИСТАХ «ДО ВЛАДИ»: СКЛАДОВІ ТА ОСОБЛИВОСТІ (1920-1930-ТІ РОКИ)*
}

\author{
О. Л. Рябченко
}

\begin{abstract}
Рябченко О. Л. Конструювання «Я-образу» студентів вищих навчальних закладів України в листах «до влади»: складові та особливості (1920-1930-ті роки). У статті здійснюється аналіз листів студентів українських вищих навчальних закладів «до влади», визначається їх жанрова специфіка, дається характеристика особистості адресантів за допомогою виділення їхніх основних ідентифікаційних компонентів. У цих листах студенти чітко описують своєпоходження, родинні зв'язки, визначають свої сучасні і майбутніролі у суспільстві, надають собі самооцінку. Такі ідентифікаційні характеристики важливі дляаналізу процесу формування пролетарської ідентичності. Аналіз листів свідчить, що механізм ії формування у студентів 1920-1930-х рр. був усвідомленим, переважно пролетарська ідентичність набувалася під впливом зовнішніх факторів, навіть за готовими стандартами.

Ключові слова: студенти; ідентичність; «Я-образ»; листи; культурний простір; чистки; рефлексія.
\end{abstract}

Рябченко О. Л. Конструирование «Я-образа» студентов высших учебных заведений Украины в письмах «во власть»: составляющие и особенности (1920-1930-е годы). В статье проводится анализ писем студентов украинских вузов «во власть», определяется их жанровая специфика, дается характеристика личности адресантов посредством выделения их основних идентификационных компонентов. В этих письмах студенты четко описывают свое происхождение, родственные связи, определяют свои современные и будущие роли в обществе, дают себе самооценку. Эти характеристики важны для анализа процесса формирования пролетарской идентичности. Анализ писем свидетельствует, что механизм ее формирования у студентов 1920-30-х гг. был осознанным, преимущественно пролетарская идентичность приобреталась под. влиянием внешних факторов, даже по готовым стандартам.

Ключевые слова: студенты; идентичность; «Я-образ»; письма; культурное пространство; чистки; рефлексия.

Ryabchenko O. L. Constructing of the «I-image» of the Students of Higher Educational Institutions of Ukraine in the Letters «To the Authorities»: Components and Specific Features (1920s-1930s). The article analyses the letters of the students of Ukrainian higher educational establishments "to the authorities", determines the specific features of the genre, and describes the personalities of the addressees by defining their main identifying components. These letters represent peculiar identification characteristics as the students clearly describe their origin, family ties, determine their present and future roles in the society, and provide self-esteem. These characteristics are important for analyzing the process of the proletarian identity forming. The analysis of the letters proves that the mechanism of the proletarian identity forming was conscious among the students of the 1920s and 1930s; mainly it was acquired under the influence of external factors by using sometimes even ready-made standards.

Keywords: students; identity; "I-image"; letters; cultural space; cleanings; reflection.

У сучасній українській історіографії все частіше об’єктом аналізу стають студенти як окрема соціально-демографічна група, зокрема, особливості їхнього повсякденного життя та джерела, що дозволяють більш-менш повно його розкрити ${ }^{1}$. Незважаючи на зростання інтересу до студентської тематики, сучасних авторів майже не цікавить студентська самосвідомість, практики їхньої повсякденності, ставлення до влади та до експериментів в різних сферах життя, достовірність і щирість запевнень молоді про відданість режиму, тощо. Здійснити своєрідну археологію ментальності допомагають его-документи, серед яких наймасовішими і надзвичайно цікавими епістоляріями радянської епохи є листи «до влади». Цим умовним терміном в історіографії прийнято позначати апеляції громадян до

\footnotetext{
* Дослідження проводиться за підтримки Наукового товариства імені Шевченка в США (Фонд Юрія Кузіва).
} 
керівництва держави, партійно-комсомольських лідерів, у всілякі комісії чи до редакцій газет та журналів. Для раннього радянського суспільства був характерний справжній епістолярний сплеск, у ті часи до радянських керманичів масово зверталися представники найрізноманітніших професій і верств населення.

Зважаючи на великий масив листів та інших его-документів, останнім часом помітно активізувалася прикладна археографія, а серед найцікавіших видань слід виділити і збірники листів «до влади», підготовлених російськими дослідниками А. Я. Лівшиним та I. Б. Орловим ${ }^{2}$. Зазначимо, що студентська кореспонденція у цих збірниках представлена поодинокими екземплярами.

При постійному зростанні кількості публікацій з студентської тематики та спробах дослідників здійснити аналіз документів, важливих для детального висвітлення різних сторін життєдіяльності молоді ${ }^{3}$, листи студентів і сьогодні залишаються незатребуваним корпусом першоджерел. Зазначимо, що у зверненнях «до влади» цінною є насамперед інтерпретація фактів і подій минулого, що постає як відображення масової та індивідуальної свідомості сучасників. Ця інформація дозволяє і досліднику, i «пересічному» читачеві побачити і зрозуміти історію через долі, переживання і суб'єктивні уявлення конкретних людей.

У наукових дослідженнях, як правило, використовують фрагменти листів лише з ілюстративною метою. Такий метод далекий від наукового, оскільки лише значна кількість джерел може бути основою для аналізу і робить аргументацію достатньою. Метою цієї статті є дослідження студентських листів «до влади», документів, що належать до сфери стосунків молоді та чиновників раннього радянського періоду: аналіз жанрової специфіки цієї кореспонденції, характеристика особистості адресантів та їхніх ідентифікаційних компонентів за допомогою методики дослідження «Я образу».

Основною причиною «епістолярного спалаху» серед студентів стали численні порушення на місцях законів і правил доступу до вищої освіти, затверджених більшовицькою владою. Звичайно, привід, що спонукав взятися за перо, був у кожного свій, проте усі без винятку випадки об'єднані однією метою - надією на позитивне вирішення проблеми першими особами держави чи вищими інстанціями та сподіванням, що на місцях змушені будуть виконати ці вказівки. Апеляції до вищих органів влади і перших осіб держави/ республіки вважалися найефективнішим способом позитивного вирішення тієї чи іншої проблеми: одні доводили своє право на вступ до навчального закладу, інші - на стипендію чи гуртожиток. Хтось ставав жертвою доносу i, втративши шанс на отримання освіти, намагався відновити справедливість.

Для аналізу були використані документи центральних, обласних та деяких вишівських архівів. Найбільше студентських листів «до влади» зберігається у фонді № 166 Центрального державного архіву вищих органів влади і управління (далі - ЦДАВО) України, де відклалися протоколи засідань комісій з перереєстрації студентів чи матеріали розгляду студентських апеляцій на спеціальних засіданнях у заступників Наркома освіти УСРР. Листи студентів 1930-х рр. у переважній більшості збереглися у архівах окремих вищих навчальних закладів, невелика їх кількість знаходиться в Центральному державному архіві громадських організацій України (далі - ЦДАГО) України.

Уже при первинному огляді студентських листів легко простежується відмінність у ї жанрових різновидах, тому відповідно до них і будується класифікація цих джерел. Ми розуміємо всю умовність такої класифікації. У нашому випадку йдеться не про ділове листування 3 його досить стійкою жанровою системою (зазначимо, що в опрацьованих нами листах часто зустрічаються елементи ділового стилю - наприклад, елементи заяви, скарги, клопотання, пояснюючої записки тощо, проте наявні і листи, написані у довільній формі). Але типологія все ж простежується досить чітко, і тому можна говорити про декілька найпоширеніших жанрових різновидів листів студентів «до влади». До першого належать листи-скарги/клопотання; це, насамперед, заяви про вступ до вишів i на робітфаки; листи-скарги студентів, «вичищених» із вишів за академічну неуспішність чи за соціальне походження; скарги про тяжке матеріальне становище та прохання про матеріальну підтримку.

У 1920-1930-ті роки спостерігається значне поширення саме листів-скарг і клопотань до найвищих інстанцій різних категорій населення. Такий жанр найбільш характерний 
і для студентів. Зазначимо, що скарги/клопотання писали студенти - представники різних соціальних верств. Так, скарги пролетарських студентів були викликані наявними невідповідностями між задекларованими більшовиками привілеями для них і тим, що вони отримували в реальності, а саме невиправданими надіями на вступ до вищих шкіл, поганим матеріальним забезпеченням, а також виключенням із вишіву результаті чисток (серед позбавлених права навчання зустрічалася навіть молодь, яка брала участь у боях, відстоюючи інтереси більшовиків). Усі такі листи просякнуті надією на позитивне вирішення проблеми.

Деякі листи містять елементи інвективи - їхня тональність свідчить про те, що у свідомості прибічників більшовицького режиму відбувалися зміни у оцінках дій влади. У таких листах ми зустрічаємо звинувачення властей у порушенні прав на навчання, критику дій представників влади на місцях, звинувачення їх у корупції і навіть погрози: «Як буде так провадитись, то як будуть нападати вороги на радянську владу, то хай ідуть ті захищать, що тепер повходили у всякі школи...»"

Іншим, досить поширеним різновидом аналізованої кореспонденції є листи-доноси. 3 початку 1920-х рр. за допомогою доносів намагалися вплинути на вирішення побутових чи навчальних проблем. Паралельно почала невпинно зростати кількість листів-сигналів про наявність у вишах класових ворогів. Дослідники справедливо відзначають, що донос - це процес перш за все інформаційний ${ }^{5}$. Дані, наведені в них, не завжди були достовірними, але повинні були привести до застосування правових чи соціальних санкцій до неугодної людини.

Явище доносу останнім часом все більше цікавить науковців, з'явилися навіть монографії, де висвітлюється історія, аналізуються прояви доносительства у різних країнах і епохах, а також висвітлюються причини, особливості і наслідки цього явища в цілому по СРСР i, зокрема, в Україні'.

Резидент НКВД Олександр Орлов (Лев Фельдбін) порівнював НКВД 1930-х років 3 величезною почтовою скринькою, скориставшись якою, кожна радянська людина могла відправити сигнал ${ }^{7}$. Такою скринькою для студентів могли стати будь-які керівні структури, створені для контролю за вишівською молоддю. Доноси писали правлінню, комісіям 3 чистки різних рівнів, у штаб Легкої кавалерії тощо. Писали не лише студенти один на одного, а й їхні знайомі чи знайомі знайомих, які в очі не бачили того, на кого доносили, писали сусіди і навіть родичі, які вказували на тих, кому, на їхній погляд, не було місця в радянській школі. Документи, що визначали політику пролетаризації, чітко окреслювали образ чужих владі студентів, практично вказували на об’єкт переслідувань. Тому комісії 3 перереєстрації були завалені як правдивою, так і брехливою інформацією.

Особливо поширеною була практика доносів у студентському середовищі з середини 1920-х до середини 1930-х рр. У всякому разі, саме за цей період їх найбільше збереглося і вдалося виявити в архівних справах. Відкрито закликали доносити один на одного також автори дописів у періодиці: «Є випадки, коли комсомолець знає про приховування соціального стану, але мовчить. На мою думку, треба всім студентам, як тільки хто знає про кого щось непевне, так й подавати заяву. Бо що то за студент, коли він не турбується за чистку свого вишу» ${ }^{8}$. Проте вибір - донести чи ні - залишався завжди. Так, серед причин виключення студента III курсу Одеського IHО Липка з інституту було і те, що, знаючи, де навчаються діти дідича з його села, він відмовлявся про це заявити‥ Аналогічні мовчазні індивідуальні протести губилися у масових викривальних кампаніях, мітингах та зборах на підтримку чисток і сотнях доносів, автори яких вболівали «за чистоту студентських лав» і які стали справою честі та геройства.

Небезпечно було й виступати на захист звинувачених, оскільки останні з метою самокритики могли зрадити привселюдно. Наприклад, у листі до редакції газети «Студент Жовтня» партієць Кравцов, виправдуючись за свої помилки «право-опуртиністичного характеру», писав: «Засуджую також примиренське ставлення до мене тов. Яновича, який намагався довести, що кваліфікувати мене, як правоухильника не можна, а кваліфікувати потрібно як панікерство та боязнь труднощів» ${ }^{10}$.

Листи-дифірамби також є досить цікавим джерелом, але їх, у порівнянні з іншими різновидами, віднайдено зовсім мало. Як правило, це палкі привітання і подяки владі, приурочені до річниць революційних свят, відкриття всіляких зборів, конференцій. Вони 
містять елементи звітів про результати навчання і громадської роботи, а також запевнення у вірності комуністичним ідеям. Розквіт і активне функціонування цього різновиду листа до влади належить ХХ століттю.

Адресати у студентських послань були різні: як перші особи держави - Й. Сталін, А. Луначарський, Н. Крупська, Г. Петровський, М. Скрипник, А. Приходько, так і вищі органи державної влади (ЦК партії, Народний комісаріат освіти) чи редакції газет. Частогусто листи дублювалися - паралельно з вищезазначеними особами, вони відправлялися керівникам вишів, до приймальних чи місцевих комісій з перереєстрації тощо. Нами віднайдено такі продубльовані листи окремих студентів до різних органів влади у різних архівосховищах. Саме вони дозволяють досить чітко уявити весь жах і тривалість процесу відновлення у правах студента.

Перевіркою інформації, поданої у листах, займалися спеціальні комісії ${ }^{11}$ місцеві, окружні, центральні та інші, наприклад, приймальні. Назви, підпорядкування, склад їх змінювався, а функції залишалися ті ж. Наприкінці 1920-х рр. до них долучилися штаби Легкої кавалерії (при вишах і при НКО). Зустрічаються справи, розслідуванням яких у 1930-ті pp. займалися уповноважені Бюро скарг Комісії радянського контролю при РНК СРСР. Встановити хоча б приблизну кількість листів, за відсутністю статистики, на разі неможливо. Маємо лише окремі факти, які свідчать про те, що у Центральній комісії 3 студентських справ до середини 1920-х рр. рахунок йшов на сотні (на грудень 1923 р. туди було направлено 486 заяв) ${ }^{12}$. У другій половині 1920-х рр. кількість скарг значно зростає: лише 3 грудня 1928 по жовтень 1929 р. до Центральної студентської комісії поступило 2400 заяв $^{13}$. На перевірку фактів, наведених у листах, як свідчать протоколи засідань, часто йшли тижні і навіть місяці. Саме ця обставина й примусила молодь звертатися до перших осіб держави або у центральні державні органи влади; у таких випадках розгляд справи значно пришвидшувався. Наприклад, у студента Київського інституту народного господарства Б. Д. Палія на відновлення у правах пішло більше двох років нервової напруги, переживань, фізичної і моральної витримки, про що він і зазначив у листі до НКО: «Я подавав заяву за заявою, апеляцію за апеляцією, довідки, свідоцтва. Все було доведено, але не відновлено. ... Де шукати правди? Чому мені не дають навчатися? За що?» ${ }^{14}$.

Разом 3 тим маємо випадки опротестування керівниками інститутів і місцевими комісіями при вишах рішення перших осіб держави та центральних комісій. Нерідко, щоб уникнути переслідування, студентів переводили до інших навчальних закладів.

30 січня 1930 р. постановою колегії НКО Центральну комісію в студсправах при НКО було ліквідовано ${ }^{15}$. Для розгляду скарг студентів, що їх було виключено із вишів внаслідок перевірки соцстану, були створені округові комісії студентських справ під головуванням старшого Окружного інспектора народної освіти або його заступника. Вони керувалися у своїй роботі попередніми обіжниками про порядок розгляду скарг. Невдовзі округові студентські комісії також були ліквідовані. Нові апеляційні комісії рекомендувалося створювати уже при міськрадах ${ }^{16}$. Очолювати їх мав представник секції наросвіти, а членами обиралися із представників міських організацій комсомолу, комітетів незаможних селян, пролетстуду та міжспілкових об'єднань. Обов'язковою була участь представника вишу, на рішення якого подано апеляцію. У постанові зазначалося: «До компетенцій комісії належить лише розгляд скарг на виключення за соцстаном, антирадянські вчинки, дезорганізація учбового життя, невитримана поведінка. Ніяких інших питань, що стосуються студентів (стипендії, гуртожитки), комісія не розглядає, як і випадки виключень за академуспішність. Постанови апеляційних комісій є остаточними й оскарженню перед органами Наркомосвіти не підлягають» ${ }^{17}$.

На наш погляд, рішення про децентралізацію комісій було викликане фактом широкого розповсюдження фальшивих документів про соціальне походження, які з легкістю можна було здобути в ті часи по знайомству чи за хабар. На місцях можна було швидше організувати перевірку наданих довідок. Допомагали у цьому представники Легкої кінноти і мережа таємних співробітників ГПУ. Крім того, на початку 1930-х рр. перевірочні комісії вимагали розслідування наданих студентами довідок у судовому порядку.

Незважаючи на реорганізації, апеляції продовжували поступати до НКО і безпосередньо до керівників цього Наркомату в масовій кількості. Наприклад, потужна хвиля скарг була викликана вимогою «посилення пильності» під час кампаній ліквідації «куркулів та 
їх приплічників» у вишах. Але усі ці листи разом із іншими виправдовуючими документами для вирішення питання пересилалися до інститутів, де навчалися студенти, з однотипними офіційними повідомленнями на бланках на зразок такого: «До Київського кооперативного інституту. Копія - гр. Бахір М. М. м. Короп, Конотопського округу. Центральна студентська комісія при цьому надсилає заяву та документи на 17 арк. гр. Бахір М. М., кол. ст. II курсу ККІ на ваше остаточне вирішення. Підстава: постанова Колегії НКО від 30/1-30 р. Секретар ЦСК» ${ }^{18}$.

При аналізі перш за все впадає в очі різниця в обсягах і стилістиці листів: одні великі, написані каліграфічним почерком чи надруковані на машинці, інші - коротенькі, досить часто написані неохайно, а деякі навіть на обривках якогось паперу (наприклад, лист П. Жривайло до заступника Наркома освіти А. Т. Приходька $)^{19}$.

На нашу думку, на основі аналізу стилістики текстів листів, кожен дослідник сьогодні може суб'єктивно оцінити рівень рефлексії студентів. Стиль - логічність доказів, послідовність викладу, аргументація, можливість віднайти необхідні докази на спростування звинувачень - сам по собі може сказати багато про адресанта.У цьому сенсі варто пригадати слова Жоржа де Бюффона: «Стиль є сама людина» („Le Style c'est l' homme même“). Вiн стверджував, що «...вміти писати - значить вміти думати, вміти відчувати і вміти пояснювати свої думки і почуття; мати розум, душу і смак; стиль вимагає об'єднання і вправи всіх розумових здібностей; основу його складають ідеї, гармонія ж слів - лише допоміжний засіб...» ${ }^{20}$. Як правило, людина з більш розвиненим рівнем рефлексії вибудовувала свою розповідь яскравіше, логічніше, знаходила переконливі аргументи і вміла їх подати у вигідному для себе світлі, доводила несправедливість прийнятих стосовно неї рішень.

Уміння написати аргументовано, чітко, переконливо довести свою необхідність для будівництва нового суспільства, мало особливо важливе значення у разі виключення із вишу у результаті чисток. Такі кампанії не були таємними, студенти знали про чергову перереєстрацію чи перевірку, навіть завчасно мали можливість підстрахуватися різними довідками, знайти необхідні документальні підтвердження для своєї розповіді. Інша річ, що значна частина виключених навіть не підозрювала, що їх позбавлять права навчання: «Восени 1924 р. - чистка. Я спокійний. До «елементів» не належу. Збираюся переходити на третій (останній) курс. Але мене виключили...», - писав до НКО України студент Київського інституту народного господарства Б. М. Палій ${ }^{21}$. Дати виключень і подання апеляцій більшості листів говорять про те, що студенти не марнували час на роздуми i вичитування своїх текстів. Характер апеляцій показує хід думок, а від уміння викласти їх на папері часто залежало майбутнє людини. Звичайно, що поспішність відбилася на стилі -оскільки тексти не були підготовленими попередньо, вони надзвичайно емоційні, 3 повторюваними сюжетами, блукаючими думками. Але і в цьому також виявляється їхня особлива привабливість для дослідника.

Слід зазначити, що переважна більшість листів свідчить про високий рівень рефлексії адресантів, що в реаліях запровадження політики пролетаризації вищої школи є свідченням логіки відбору «кандидатів на виліт». Соціальне походження та інші аргументи були зручною ширмою для виключення молоді мислячої, здатної піддавати сумніву партійні директиви, аналізувати дійсність, тобто розхитувати залізну дисципліну в партійних лавах. 3 цієї «залізної дисципліни» партійців спочатку навіть підсміювались і розважались анекдотами: «Не думай!.. А, коли думаєш - не говори!.. А як говориш - не пиши! .. Коли ж написав - зараз же пиши спростування...» ${ }^{22}$. Проте сміх цей мав властивість досить швидко трансформуватись у гіркі сльози.

Як зазначалося вище, листи студентів набирали форми ділового стилю 3 певними реквізитами - на початку зазначено, куди чи конкретно кому спрямовується звернення, вказується, від кого - прізвище, ім'я та по-батькові, інститут, курс, факультет. Закінчуються листи датою і особистим підписом. Уже перші словесні індикатори поряд із прізвищем адресанта дозволяють говорити про пріоритетну ідентичність - «Незаможника Корда I. І.», «члена партії Конотопської П. С.», «Николишина Володимира, політутікача із Галичини», «демобілізованого червоноармійия м. Ободівки Ободівського району Тульчинської округи Степана Семенова Шевчука», «студентки ІІІ курса Гольдберг Ш. 3. члена союза Рабкомхоз» тощо. Це твердження, що належать до об'єктивно визначених статусів чи класів. Перевірити їх достовірність при бажанні можна було без особливих перешкод. 
Деякі листи написані не самими студентами, а їхніми близькими родичами - наприклад, матерями, батьками, братами чи опікунами. Це може свідчити про складнощі у відстоюванні своєї думки або втрату віри у справедливе вирішення проблеми (у крайніх випадках розпач призводив до самогубств чи намірів його здійснити, про що я писала у своїх попередніх дослідженнях $)^{23}$. Для листів характерний свій особливий стиль, що у переважній більшості далекий від офіційного. Оскільки культура ділового листування не була оформленою, першим особам держави часто намагалися відкрити всю свою душу, вилити весь свій біль. Тому зустрічаються такі форми звернень до високопосадовців: «Шановний тов. Ряппо. Звертаюся до Вас, як до рідного батька, бо я знаю, що від Вас залежить вся моя будучність, все моє життя. Я прошу Вас з гіркими слізьми допомогти в моїй справі $2^{24}$, чи інший: «Не сердитесь дорогая Надежда Константиновна нет у меня кому пожалеться и кого просить помощи кроме Вас. Не оставили Вы без внимания моего первого письма спасибо большое никогда не забудем» ${ }^{25}$. Як бачимо, листи давали надію для відновлення справедливості. Свавілля місцевих комісій і незахищеність людей породжували віру в диво, віру в рятівну силу звернення до сильних світу цього. Російські дослідники, зокрема А. Сорокін, відзначають, що ця віра породжена традиціями колишньої чолобитної культури, в якій проявилося чітке уявлення низів про сутність бюрократичної системи управління ${ }^{26}$. Разом 3 тим листи свідчать, що, $з$ одного боку, молодь дійсно від влади очікувала традиційної «милості», а з іншого вимагала справедливості, дотримання своїх прав на освіту, показувала свою незгоду з діями місцевих комісій чи інших осіб.

Тривале дослідження студентської кореспонденції говорить про те, що більш цікавим i результативним, на наш погляд, $є$ аналіз такого роду документів не за піджанрами / різновидами, а за сюжетним наповненням.

Апеляції студентів - це не просто звернення до влади про поновлення у правах чи про матеріальну підтримку. Листи цікаві перш за все самоаналізом молодих людей, роздумами над ситуацією, в якій вони опинилися, над власним душевним станом, пошуками виправдань, «каяттям» за неіснуючі гріхи чи, навпаки, вимогами відновлення справедливості у відношенні до них і навіть погрозами. Листи студентів демонструють стратегії поведінки в різних ситуаціях, варіанти прийняття рішень - як раціональних, так і навпаки.

Для характеристики адресантів, у нашому випадку - людей минулих епох, вважаємо доцільним застосовувати методику дослідження «Я-образу», що є досить популярною при вивченні соціальної і особистісної ідентифікації людини, на основі установок на адресу самої себе. У науковій літературі поняття «Я-образ» 3'явилось у зв'язку з потребою дослідження глибинних психологічних структур і процесів особистості. Воно використовується разом з такими поняттями як «самосвідомість», «самооцінка», «Я-концепція», «Я», «уявлення про себе» і неподільно з ними пов'язано. До сьогодні зміст і обсяг цього поняття так і залишається дискусійним. Центральною функцією «Я-образу» є ідентичність - структура динамічна, що розвивається протягом усього життя людини.

На нашу думку, характеристики, записані студентами на початку листів, були найбільшою мірою актуалізовані в їхній свідомості, тому найбільш усвідомленими і значущими для суб'єкта. Найчастіше розповідь починалася із констатації свого класового походження - син села, селянин/робітник з діда-прадіда тощо. У одних випадках наявна просто фіксаціятакого факту, в інших - розлогі розповіді про батьків і навіть різних родичів-пролетарів. Так, студент Харківського медичного інституту Дубровін (Дуброва) П. О. зазначав: «Дед мой (по матери) был рабочим; почти всю свою жизнь прослужил на эллинге Русского О[бщест]ва пароход[ства]. и торг[овли]. в г. Одессе. Дед мой по отцу Ф. К. Дуброва был крепостным крестьянином поміщика Комиссарова[,] деревни Комиссаровки[,] Староверовской волости[,] Купянского уезда[,] Харьковской губернии. В 1861 году он был освобождён из крепостной зависимости. Не имея земли, он переехал на жительство в г. Купянск, где и приписался к Купянскому мещанскому обществу. Семью он омел большую: одиннадцать человек детей, средств содержать их не было и он определил их на выучку в различные мастерские, некоторых же в магазины - мальчиками. Отец мой 12 лет был отвезён им в г. Харьков и определён мальчиком в обувный магазин С. Я. Токаревой....» ${ }^{27}$.

Такі розлогі розповіді були особливо необхідні у випадку, коли було відомим непролетарське походження студента. Наприклад, М. С. Шелудченко (Київський інститут народної 
освіти) зазначав, що його батько виконував обов'язки служителя релігійного культу тільки з 1913 р., а до того часу дев’ятнадцять років був учителем і походив із селян. «Зараз він живе в своєму селі і нарівні з усіма селянами обробляє землю своїми власними силами. Це дає мені право вважатися селянином ${ }^{28}$.

Важливими складовими Я-образу студентів виступають категорії, якими позначалась наявність пролетарської свідомості. По-перше, молодь намагалася довести, що походження і переконання - речі різновекторні. Так, студент Кам'янецького сільськогосподарського інституту В. М. Лапінський писав (1.06.1923р.): «... я сын священника и таким образом являюсь якобы непролетарским элементом. С этим я глубоко не согласен. Если даже предположим, что отец мой не пролетарий, то при чём здесь я, пошедший совсем по другой дороге. Да, наконец, если я уже сын священника, то неужели я должен быть враждебно настроен к советской власти? Неужели я не могу бать полезным работником в республике...» ${ }^{29}$. Студенти досить детально описували дитинство і юність, показували, як змінювалися їхні уявлення про релігію, життя, як трансформувався їхній світогляд, намагалися переконати комісії, що вони мають різні переконання з батьками.

Тобто, за результатами аналізу сюжетів текстів можемо констатувати наявність складних словесних обертів, раціональні обгрунтування наявності пролетарської свідомості, що є характеристикою високого вербального інтелекту авторів. Доволі розповсюдженою при конструювання Я-образу є категорія «не маю нічого спільного із світоглядом батька» або констатація факту розриву з батьками і відречення від них, що є яскравим проявом захисних механізмів психіки. Так, студент Полтавського сільськогосподарського інституту I. П. Щербань за те, що його батько «підпав під куркульський вплив і по своїй несвідомості і некультурності виступив проти хлібозаготівель», перестав визнавати його «за батька, зовсім відмовився від нього і назавжди порвав 3 ним всякі зв'язки ${ }^{30}$. Про це він відразу ж повідомив ректора і надіслав повідомлення в газети «Комуніст» та «Вісті» ${ }^{31}$.

Іноді у листах можна помітити амбівалентність позиції щодо сім’ї. Наприклад, у листі С. Підгайного це проявляється в тому, що на початку листа, розповідаючи про свою родину, автор усвідомлює себе членом сім'ї та намагається заперечити обвинувачення «...моїх батьків характеризують як куркулів, якими вони ніколи не були і не $\epsilon . . »$; «я і мої батьки належать до середняків»; «...батько не був контрреволюціонером, а був розстріляний як заложник...». Всередині листа вже маємо іншу картину. Заради досягнення власних цілей автор листа відхрещується від батька та брата («...основне і головне те, що я ані з батьком, ані з братом не маю нічого спільного...Я завжди йшов поруч з кращими товаришами..., ніяким способом не користувався з батьківського господарства..., я нічого спільного не маю 3 політично-ідеологічним світоглядом мого батька...» ${ }^{32}$ ). Цей факт амбівалентності позиції може бути пояснений внутрішньою конфліктністю, емоційними переживаннями та ваганнями між індивідуальними/сімейними та груповими/класовими інтересами.

У інших випадках молодь навідріз заперечувала свої стосунки з непролетарською родиною і навіть клопоталася про зміну прізвища, про що читаємо, наприклад, у тексті студента четвертого курсу Катеринославського медичного інституту Л.-І. П. Казаковського: «С родными ничего общего не имею и ходатайствую для предупреждения могучих быть и впредь недоразумений об изменении моей фамилии» ${ }^{33}$. Дані факти говорять про відсутність сімейної згуртованості, сімейних цінностей, готовність зрадити рідних людей заради захисту своєї безпеки та досягненню власних цілей.

Досить часто виключені намагалися довести, що знаходяться на утриманні інших родичів - 3 вигідним походженням чи заслугами перед революцією. Навіть А. Луначарський у своєму листі до М. Скрипника з приводу вичищеного із Одеського інституту народної освіти брата уповноваженого окружного ОГПУ Одеської обл. Слинявка зазначав, що при виключенні із вишів варто брати до уваги такі фактори: «...нельзя же не принять во внимание, что с отцом своим связи у студента нет, что сім'я его коммунистическая, что брат, который помогает и руководит им в жизни, видный работник ОГПУ. Если мы будем бить по таким семьям за их отцов, то это чёрт знает что» ${ }^{34}$.

Наступною категорією, якою підтверджувалась наявність пролетарської свідомості, був акцент на заслугах своїх чи родичів перед революцією. Так, студент Харківського технологічного інституту П. П. Олешко писав: «Отец мой бедняк, член колхоза с 1923 г., принимал активное участие в революции, красный партизан и организатор красных отря- 
дов. Я же, начиная с 1917 по 1922 г., служил добровольно в Красной Армии, красный партизан. Год прослужил в Чека. Пол года был политруком в милиции.... ${ }^{35}$. Важливими у описах були навіть такі деталі, як протиставлення своєї поведінки позиції інших: «... в 1918 году, корда большая часть интеллигенции саботировала, я служил на Советской службе - в Харьковском Губземотделе (счетоводом), отец же занимал в Ахтырском уезде ответственную и довольно опаную должность заведующего советским ссыпным пунктом. Во время нахождения белых в Харькове у нас занимал комнату коммунист тов. Гостев, что нам было известно - мы его не выдали, и он жив до сих пор» ${ }^{36}$.

Таким чином, вказуючи на свої заслуги, студенти намагалися виправдати себе перед владою, довести наявність «пролетарської свідомості». Особливо підкреслювались служба у Червоній армії, участь у боях, робота в ЧК, членство в партії, комсомолі чи профспілках. Трудова діяльність і наявність виробничого стажу також входили до цього переліку. Як правило, студенти робили простий перелік посад, на яких їм доводилось працювати, але форма подачі матеріалу може багато сказати про автора як особистість. Наприклад, вислови виключеного із Полтавського інституту народної освіти К. Г. Мигаля про свою суспільно-корисну діяльність ${ }^{37}$ : «...працював в касі взаємодопомоги...; був скарбником...» говорять про відповідальність автора і довіру до нього з боку колег; фраза: «...був керівником гуртка мистецтвознавства....» свідчить про інтерес до мистецтва, історії, а також наявність управлінських якостей; а слова: «...був уповноваженим по втягненню студентів до ячейки «Лікбезу» - про наявність комунікативних здібностей, вміння переконувати. У цілому словесні висловлювання К. Мигаля характеризують його як достатньо активного студента, котрий мав різносторонні інтереси, комунікативного, авторитетного.

Досить цікавою для нас є така суб’єктивна категорія «Я-образу», як представлення себе як «чесного», «вірного», «відданого» громадянина радянської землі, що означало, перш за все, вчасно повідомити про тих, чиї погляди відрізняються від загальноприйнятих партією. Викриття і звинувачення інших було механізмом захисту себе від можливих негативних наслідків. Особливий дисонанс з позицій сьогодення викликають такі самопрезентації тих студентів, у листах яких переважають позитивні суб' єктивні оцінки. Наприклад, згаданий вище К. Г. Мигаль вказує на студента Костю Міхна, який є сином поміщика, але отримує стипендію, і відразу ж раціонально обгрунтовує свою поведінку - «...виконую обов'язки чесного громадянина радянської землі...»» ${ }^{38}$.

Наявна у листах і така важлива категорія конструювання «Я-образу» як тяжке матеріальне становище/бідність студента чи його родини. Бідність і нестатки у багатьох випадках ототожнювалися 3 робітничо-селянським походженням, але також були козирною картою і в листах вихідців із колишніх. Автори акцентували на труднощах, скруті, надзвичайній бідності, яка булла перешкодою для отримання освіти, оскільки потрібно було працювати, щоб прогодувати сім'ю. Характерним було протиставлення можливостей доступу до освіти за царизму і тепер. Вимушена праця з раннього дитинства давала можливість зарахувати себе до трудового народу, стати «своїм». Так, В. Германова відзначала: «Нас было много у отца, но никто из нас не пошёл по линии общественно бесполезного труда. Нужда с раннего детства, включительно до настоящего времени, заставила стать нас в ряду честных тружеников. Мы своими собственными усилиями, своїми собственными трудами пробивали и пробиваем дорогу к знанию. Это тяжело, но кто испытал, тот поймёт» ${ }^{39}$.

Цікаво, що категорії «Я-образу», яка говорить про академічну успішність студентів, як правило, відводиться чи не останнє місце навіть у листах виключених за неуспішність, що також свідчить про першочерговість доказу молоддю своїх пролетарських, ідеологічних інтересів, а потім вже професійних. Слід також зазначити, що предмет скарги, як правило, описувався чітко, а це говорить про глибоке розуміння сутності політики, законодавчої бази, своїх прав та обв'язків.

Межі статті не дозволяють всебічно висвітлити анонсовану проблему, тому грунтовний iï аналіз - це завдання наступних досліджень. Важливим $\epsilon$, наприклад, аналіз психолінгвістичного аспекту ідентичності на основі аналізу найчастіше вживаних студентами частин мови чи часових форм, що важливо для характеристики їхнього внутрішнього світу в цілому, а також бачення ними своїх перспектив, прийняття чи задоволеність сьогоден- 
ням. За допомогою такого аналізу можна говорити про те, людина з якими ідентифікаційними характеристиками була успішною у ранньому радянському суспільстві, від набору яких характеристик залежав успіх інтеграції, тобто кар'єра і навіть особисте життя.

Таким чином, поняття листи «до влади» включає в себе різні форми письмового спілкування $з$ керівниками держави різних рівнів. Такі документи дають можливість побачити специфіку політичних взаємин в радянський період і говорити про ефективність цієї комунікації.

Студентські роки були важливим етапом у формуванні самопізнання і світогляду молоді. Становлення самоусвідомлення у цей період відбувається через формування стійкого образу своєї особистості, свого «Я». Листи студентів 1920-1930-х рр. являють собою своєрідні ідентифікаційні характеристики, в яких чітко розкривається тема походження, родинних зв'язків, представлено бачення своїх сучасних і майбутніх ролей у суспільстві, самооцінка молоді. Ці характеристики важливі для аналізу процесу формування пролетарської ідентичності. Аналіз листів свідчить, що механізм їі формування у студентів 1920-1930-х рр. був усвідомленим, переважно пролетарська ідентичність набувалася під впливом зовнішніх факторів, навіть за готовими стандартами.

${ }^{1}$ Рябченко О. Студенти радянської України 1920-1930-х років: практики повсякденності та конфлікти ідентифікації. Харків: ХНАМГ, 2012. 456 с.; Комарніцький О. Б. Студенти-педагоги у модернізації вищої освіти Радянської України у 1920-1930-х рр. Кам’янець-Подільський: ТОВ «Друкарня Рута», 2017. 984 с.; Рожков А. Ю. В кругу сверстников: Жизненный мир молодого человека в советской России 1920-х годов: в 2 т. Т. 1. Краснодар: Перспективы образования, 2002. 404 с.; Марков А. Что значит быть студентом. Работы 1995-2002 гг. М.: НЛО, 2005. 264 с. та ін.

2 Лившин А. Я., Орлов И. Б. Письма во власть. 1917-1927. Заявления, жалобы, доносы, письма в государственные структуры и большевистским вождям. М.: РОССПЭН, 1998. 664 с.; Лившин А. Я., Орлов И. Б., Хлевнюк О. В. Письма во власть. 1928-1939. М.: РОССПЭН, 2002. 525 с.; Последние письма Сталину. 1952-1953 гг. Реконструкция документального комплекса / Сост.: Г. В. Горская, М. С. Астахова, В. Деннингхаус и др. М.: РОССПЭН, 2015. 542 с.

3 Лаврут О. О. Джерела до вивчення історії студентства УСРР 20-х років ХХ ст. // Історичний архів. Наукові студії. 2011. № 6. С. 115-119; Лаврут О. О. «Відчит Центрального бюро пролетарського студентства до III Всеукраїнського з'їзду пролетарського студентства» як джерело до вивчення життя молоді вищих навчальних закладів УСРР // «Гілея: науковий вісник»: Збірник наукових праць. К., 2011. Випуск 46 (4). С. 219-224.

${ }^{4}$ Центральний державний архів вищих органів влади і управління (далі - ЦДАВО) України. Ф. 166. Оп. 4. Спр. 700. Арк. 669.

${ }^{5}$ Нехамкин В. А. Донос как социально-психологический феномен (из отечественного опыта 1930-х годов) // Историческая психология и соціологія истории. Т. 7. № 2. 2014. С. 66.

${ }^{6}$ Игнатов В. Д. Доносчики в истории России и СССР. М.: Вече, 2014. 416 с.

${ }^{7}$ Орлов А. Тайная история сталинских преступлений. М.: Всемирное слово, 1991. 352 с.

${ }^{8}$ Ворог напирає. До чистки вишів (ХІНО) // Студент революції. 1930. № 4. С. 49. Підпис: О. К-н.

9 Державний архів Одеської області. Ф. Р-1593. Оп. 1. Спр. 780. Арк. 79.

10 Лист до редакції «Студент Жовтня» // Студент жовтня. Орган студентів, професорів, викладачів та службовців інститутів: Інженерно-економічного, пляново-економічного, обміну й розподілу та Радянського будівництва і права. Харків, 1931. 2 січня. № 6 (58). Підпис: член партії Кравцов

${ }^{11}$ Хто розглядатиме скарги вступників до ВИШів // Вісти. 1929. 13 вересня.

${ }^{12}$ ЦДАВО України. Ф. 166. Оп. 2. Спр. 1573. Арк. 417.

${ }_{13}$ Там само. Оп. 9. Спр. 315. Арк. 28.

${ }^{14}$ Там само. Оп. 6. Спр. 10514. Арк. 444.

${ }^{15}$ Там само. Оп. 9. Спр. 1736. Арк.210.

${ }^{16}$ Там само. Оп. 9. Спр. 1736. Арк.13.

${ }^{17}$ Там само. Оп. 9. Спр. 1736. Арк. 13.

${ }_{18}^{18}$ Там само. Оп. 6. Спр. 10558. Арк. 34.

${ }^{19}$ Там само. Оп. 9. Спр. 52. Арк. 303.

${ }^{20}$ Мильчина В. А. О Бюффоне и его «Стиле» // Новое литературное обозрение. 1995. № 13. C. 157-165. URL: http://www.infoliolib.info/philos/buffon/bufmilch.html (дата обращения: 04.09.17).

${ }^{21}$ ЦДАВО України. Ф. 166. Оп. 6. Спр. 10514. Арк. 444.

${ }^{22}$ Гарба В. На розпуттях (до історії одного покоління). Нью-Йорк, 1976. С. 320.

${ }^{23}$ Див.: Рябченко $O$. Л. Чистки студентського складу вищих навчальних закладів радянської України у 1920-ті роки // Український історичний журнал. 2010. № 5. С. 136-152. 
${ }^{24}$ ЦДАВО України. Ф. 166. Оп. 6. Спр. 10513. Арк. 3.

${ }^{25}$ Там само. Спр. 10510. Арк. 131.

${ }^{26}$ Сорокин А. Пионеры страны Советов: письма во власть // Родина. 2013. № 12. С. 96.

${ }^{27}$ ЦДАВО України. Ф. 166. Оп. 2. Спр. 1573. Арк. 221-223.

${ }^{28}$ Там само. Оп. 4. Спр. 710. Арк. 154, 155.

${ }^{29}$ Там само. Оп. 2. Спр. 1573. Арк. 341.

${ }^{30}$ Там само. Оп. 6. Спр. 10558. Арк. 722зв.

${ }^{31}$ Вісти ВУЦВК. 1930. 22 лютого.

${ }^{32}$ ЦДАВО України. Ф. 166. Оп. 9. Спр. 324. Арк. 393.

${ }_{33}^{3}$ Там само. Оп. 4. Спр. 712. Арк. 23-24.

${ }^{34}$ Російський державний архів соціально-політичної історії. Ф. 142. Оп. 1. Спр. 481. Арк. 9.

${ }^{35}$ ЦДАВО України. Ф. 166. Оп. 9. Спр. 1417. Арк. 116-117.

${ }^{36}$ Там само. Оп. 2. Спр. 1573. Арк. 221-223.

${ }^{37}$ Там само. Оп. 5. Спр. 604. Арк. 79-79зв.

${ }^{38}$ Там само. Оп. 5. Спр. 604. Арк. 79зв.

${ }^{39}$ Там само. Оп. 4. Спр. 710. Арк. 160-161. 